\title{
Food Security in the South Pacific Island Countries with Special Reference to the Fiji Islands
}

\author{
K. L. Sharma*
}

June 2006

\begin{abstract}
This paper analyses the status of food security in selected South Pacific Island countries, namely Cook Islands, Fiji Islands, Papua New Guinea, Samoa, Solomon Islands, Tonga, and Vanuatu at the national and household levels during the period 1991-2002. Due to narrow resource base and production conditions, Pacific Islands concentrate on a few primary commodities for production and exports. During recent years import dependency for food items has increased mainly due to a decline in per capita food production and a rapid rate of rural-urban migration. Currently, export earnings can finance food imports but earnings could fall short of the requirements needed after the expiry of some commodity preferential price agreements with importing countries. National food security is dependent on the continuation of subsistence farming and tapping ocean resources in conjunction with the on-going commercial farming of those crops in which Pacific Islands have a comparative advantage. Increased productivity is crucial for improving agricultural performance through government investment in rural infrastructure, agricultural research and extension, irrigation and appropriate price incentives. This would also help alleviate poverty for improvement in economic accessibility of food by households. There is also a need to design appropriate disaster risk management programmes to minimize any adverse effects on the food supply.
\end{abstract}

Keywords: food security, Pacific Island countries, trade, self-reliance

JEL classification: I31, Q18, O15

Copyright @ UNU-WIDER 2006

* School of Economics, the University of the South Pacific, email: sharma_kl@usp.ac.fj

This paper was prepared for the UNU-WIDER project on Hunger and Food Security: New Challenges and New Opportunities, directed by Basudeb Guha-Khasnobis. The project was carried out in collaboration with the Indian Council of Social Science Research (ICSSR) and the UN Food and Agriculture Organization (FAO).

UNU-WIDER acknowledges the financial contributions to its research programme by the governments of Denmark (Royal Ministry of Foreign Affairs), Finland (Ministry for Foreign Affairs), Norway (Royal Ministry of Foreign Affairs), Sweden (Swedish International Development Cooperation Agency-Sida) and the United Kingdom (Department for International Development). 


\section{Acknowledgement}

The author gratefully acknowledges computational assistance from Ms Nalini Lata, School of Economics at the University of the South Pacific.

The World Institute for Development Economics Research (WIDER) was established by the United Nations University (UNU) as its first research and training centre and started work in Helsinki, Finland in 1985. The Institute undertakes applied research and policy analysis on structural changes affecting the developing and transitional economies, provides a forum for the advocacy of policies leading to robust, equitable and environmentally sustainable growth, and promotes capacity strengthening and training in the field of economic and social policy making. Work is carried out by staff researchers and visiting scholars in Helsinki and through networks of collaborating scholars and institutions around the world.

www.wider.unu.edu

publications@wider.unu.edu

UNU World Institute for Development Economics Research (UNU-WIDER)

Katajanokanlaituri 6 B, 00160 Helsinki, Finland

Camera-ready typescript prepared by Liisa Roponen at UNU-WIDER

The views expressed in this publication are those of the author(s). Publication does not imply endorsement by the Institute or the United Nations University, nor by the programme/project sponsors, of any of the views expressed. 


\section{Introduction}

Food security is a common challenge for all developing nations, and small islands are no exception. In a broader sense food security as defined by the FAO is 'the ability of all people at all times to have both physical and economic assess to a sufficient amount of safe and nutritious food which meets their dietary needs and food preference for an active and healthy life'. This implies availability and stability of food supplies at the national level, and physical and economic accessibility of required food at the household level.

The objective of this paper is to analyse the status of food security in selected South Pacific Island countries during the period 1991-2002, and identify the role of trade, domestic marketing systems and government policies in improving the food security situation at the national and household levels. Strategies to reduce food insecurity are also discussed. The countries selected for the study are: Cook Islands, Fiji Islands, Papua New Guinea, Samoa, Solomon Islands, Tonga, and Vanuatu. The FAO time-series data on production and trade of agricultural commodities are used for the analysis.

The paper is divided into eight sections. In the second section, a brief description of basic demographic indicators and special problems of island countries is presented as background for analysing food security. This section also describes consumption patterns. In section 3, macro food security is analysed in terms of trends in food and agricultural production, and import dependency. Trade in food products, export earnings, and self-reliance in food are ascertained in section 4. Food distribution systems are described in section 5 . Household food security with a focus on socioeconomic characteristics and poverty is discussed in section 6. Strategies to reduce food insecurity are discussed in section seven followed by concluding remarks in section 8 .

\section{Background}

When analysing food security, it is imperative to have some background of small island countries in terms of their socioeconomic characteristics, their special problems, and consumption patterns.

\subsection{Demographic characteristics}

South Pacific Island countries are spread over a vast area of the Pacific Ocean, occupying an area of over 30 million square kilometres but only 525,000 square kilometres in total land area. These islands differ widely in size and population. Table 1 depicts key indicators of the selected island countries. Papua New Guinea is the largest country occupying around 83 per cent of the region's total land area $\left(462,000 \mathrm{~km}^{2}\right)$ with a population of 5.6 million in 2003. Other larger islands are Solomon Islands (28,000 $\left.\mathrm{km}^{2}\right)$, Fiji Islands $\left(18,000 \mathrm{~km}^{2}\right)$, and Vanuatu $\left(12,000 \mathrm{~km}^{2}\right)$. Among the selected island countries, Cook Islands are the smallest, with a land area of $237 \mathrm{~km}^{2}$ and a population of 18,000 .

Annual population growth during 1995-2002 was about 1 per cent in Fiji and less than 1 per cent in Samoa, and Tonga (Table 1). Papua New Guinea recorded the highest 
annual growth rate of 5 per cent with a population of 5.6 million in 2002. Growth of population was 3.7 per cent in Solomon Islands and 2.6 per cent in Vanuatu. In Cook Islands, a large number of people have migrated to New Zealand since 1995 and, therefore, the rate of population growth was negative for that period. Tonga is a densely populated country with 126 people per square $\mathrm{km}$ in 2002. Urbanization is increasing at a rapid rate in all island countries due to migration from rural areas. Urban population grew at an annual rate of 4.2 per cent in Solomon Islands and Vanuatu during 1990-2003 and 2 to 3 per cent in Fiji and Papua New Guinea during the same period.

People in most of the Pacific Islands have a life expectancy ranging from 66 to 71 years for males and 70 to 75 years for females, according to 2000 data (Table 1). Human development index for the Fiji Islands, Samoa, and Tonga was between 0.758 to 0.787 in 2002, much higher than in some more developed countries of Asia.

Table 1

Demographic characteristics of the South Pacific Island countries

\begin{tabular}{|c|c|c|c|c|c|c|c|}
\hline & 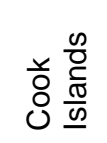 & $: \frac{\frac{n}{D}}{\frac{D}{n}}$ & 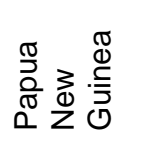 & 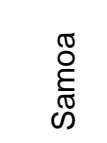 & 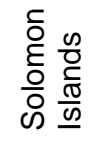 & $\begin{array}{l}\text { б } \\
\text { ర్ } \\
\stackrel{0}{-}\end{array}$ & 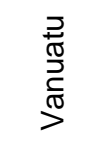 \\
\hline No. of islands & 15 & 300 & - & 8 & 100 & 200 & - \\
\hline No. of inhabited islands & 14 & 100 & - & 8 & 90 & 40 & - \\
\hline Land area $\left(\mathrm{km}^{2}\right)$ & 237 & 18333 & 462243 & 2935 & 28370 & 649 & 12190 \\
\hline Exclusive economic zone $\left(\mathrm{km}^{2}\right)$ '000 & 1830 & 1135 & - & 96 & 1116 & 596 & 857 \\
\hline \multicolumn{8}{|l|}{ Population ('000): } \\
\hline 1990 (mid-year) & 17.0 & 737.0 & 3690.0 & 160.3 & 319.0 & 96.4 & 147.3 \\
\hline 2000 (mid-year) & 18.0 & 810.4 & 5190.0 & 170.7 & 459.0 & 100.3 & 191.7 \\
\hline 2002 (mid-year) & 18.4 & 826.0 & 5620.0 & 177.7 & 456.0 & 101.0 & 202.2 \\
\hline \multicolumn{8}{|l|}{ Population density (per $\mathrm{km}^{2}$ ): } \\
\hline 1990 & 72 & 40 & 8 & 57 & 11 & 121 & 12 \\
\hline 2002 & 78 & 45 & 12 & 64 & 17 & 126 & 17 \\
\hline \multicolumn{8}{|l|}{ Annual population growth rate (\%): } \\
\hline $1990-95$ & 2.7 & 0.8 & 2.0 & 0.5 & 3.7 & 0.2 & 2.7 \\
\hline 1995-2002 & -1.5 & 1.1 & 4.9 & 0.8 & 3.7 & 0.6 & 2.6 \\
\hline 1990-2002 & 0.7 & 1.0 & 4.4 & 0.9 & 3.6 & 0.4 & 3.1 \\
\hline \multicolumn{8}{|l|}{ Urban population: } \\
\hline$\%$ of total in 1990 & 57.9 & 41.6 & 15.0 & 21.3 & 14.5 & 31.3 & 18.7 \\
\hline$\%$ of total in 2003 & 70.2 & 51.7 & 13.2 & 22.3 & 16.5 & 33.4 & 22.0 \\
\hline $\begin{array}{l}\text { Rate of growth (\%) during 1990- } \\
2003\end{array}$ & 1.3 & 2.9 & 2.2 & 1.3 & 4.2 & 1.2 & 4.2 \\
\hline \multicolumn{8}{|l|}{ Life expectancy at birth: } \\
\hline Male & 68.4 & 70.7 & 58.0 & 66.5 & 68.9 & 65.5 & 65.5 \\
\hline Female & 71.5 & 75.1 & 59.0 & 72.1 & 73.8 & 70.5 & 69.5 \\
\hline HDI value, 2002 & - & 0.758 & 0.542 & 0.769 & 0.624 & 0.787 & 0.570 \\
\hline
\end{tabular}

Note: $\quad \mathrm{HDI}=$ human development index.

Sources: SPC (2000), ADB (2004), UNESCAP (2003), UNDP (2004), Rappaport, Muteba and Therattil (1971). 


\subsection{Problems of small island economies and food security}

Small island economies share common problems with the developing countries but there are also some special problems, which need to be addressed in the context of food security. Srinivasan (1986) discusses the problems of small economies while examining the costs and benefits of being a small and remote island. These problems include lack of economies of scale in production of goods and services; high vulnerability to natural disasters; and remoteness as a result of being far from major ports and markets. Srinivasan concludes that many of the alleged problems of small economies are either not peculiar to small economies or can be addressed through suitable policy measures. Streeten (1993) describes the characteristics of small economies and discusses the advantages and disadvantages arising from these characteristics. It is shown that small economies tend to be less diversified and to have relatively high foreign trade risks. Briguglio (1995) also discusses the disadvantages of small-island developing states in detail while constructing a composite index of vulnerability. These disadvantages are classified under five headings: small size, remoteness and insularity, disaster proneness, environment fragility, and other factors. Briguglio concludes that these factors render the economies of these islands very vulnerable to forces beyond their control.

Briefly, there are three major problems in small island economies affecting their food security: smallness, remoteness, and vulnerability. Small size (in terms of population, land area, and GNP) limits natural resource endowments, makes the country dependent on a narrow range of products, and increases import dependence. Remoteness is obvious in problems with transport and communications. Distance and infrequent transport also create uncertainties in the supply of products, especially to the outer islands. Small islands are very vulnerable to natural disasters caused by cyclones, hurricanes, floods, earthquakes, landslides, and adverse weather conditions. These natural calamities devastate the agricultural sector, properties, and human life, causing tremendous loss for small islands.

Recently, McKenzie, Prasad, and Kaloumaira (2005) have assessed the economic impacts of natural disasters on development in the Pacific. The experiences of the selected sectors in Fiji, Niue, Tuvalu and Vanuatu demonstrate that past natural hazards have resulted in significant direct, indirect and intangible impacts both in the short and long term. Due to lack of data, the full impact could not be determined. For Fiji the impact of cyclone Ami in 2003 was estimated at a loss of about F\$66 million for the agricultural sector. This includes damages to subsistence and commercial crops, infrastructure and farmland.

In the islands, food crises arise in connection with natural disasters. Commercial and food crops are destroyed. Some areas are cut off from the main islands due to floods. People are relocated to designated areas. Food supply is interrupted and people cannot access the food. In Fiji, short-term relief measures are undertaken by the National Disasters Management Office (NDMO) through its network to supply food to affected areas. Government procures food from overseas donor agencies such as the Red Cross, NGOs, and government to government assistance to supplement its supply. There are delays in food supply, and a lack of coordination among the various agencies involved in food distribution. Food crisis can last for a few weeks depending upon the severity of a disaster. People start to grow food on the farmlands, but it takes a couple of months to restore the food supply. There has been no attempt at designing appropriate disaster risk management programmes to minimize adverse effects in the long run. 


\subsection{Consumption patterns}

Dietary patterns vary to some extent among the Pacific Island countries. However, there are common diet items for people in rural and urban areas.

\begin{tabular}{ll}
\hline \multicolumn{1}{c}{ Rural areas } & \multicolumn{1}{c}{ Urban areas } \\
\hline $\begin{array}{l}\text { Staple food (energy food): Roots and tubers: } \\
\text { these are taro, cassava, kumala (sweet potatoes). } \\
\text { Occasionally, rice and bread are also consumed. }\end{array}$ & $\begin{array}{l}\text { Staple food (energy food): Rice, roti, bread, is also } \\
\text { consumed in addition to roots and tubers. }\end{array}$ \\
$\begin{array}{ll}\text { Protein food: Fish, beef, chicken, eggs. Some } \\
\text { tinned meat is also consumed from time to time. }\end{array}$ & $\begin{array}{l}\text { Protein food: Tinned fish and meat, chicken, eggs, } \\
\text { cheese, dried peas, milk and fresh items. }\end{array}$ \\
$\begin{array}{l}\text { Other food: Sugar, biscuits, papaya, banana, } \\
\text { breadfruit, butter, green leafy vegetables, coconut } \\
\text { drink. }\end{array}$ & $\begin{array}{l}\text { Other food: Sugar, tea, coffee, biscuits, porridge, } \\
\text { fruits and vegetables }\end{array}$ \\
\hline
\end{tabular}

The main difference between the rural and urban dietary patterns is that in the rural areas fresh food products, including fish, are consumed while in urban areas more tinned products, rice and bread are used. In the Fiji Islands, roti, dhal, rice, bread, biscuits, milk, and other dairy products are most common in urban and rural areas for both Fijians and Indo-Fijians. A large portion of the population also uses potatoes, onions, garlic, beverages, and drinks.

Consumption expenditure data on food items are not available for the Pacific Island economies. Recently, a household income expenditure survey was conducted in the Fiji Islands for both urban and rural areas. The reference period for the urban survey is 2002-03 and for the rural survey is for 2003-04. Some provisional results of the urban survey have been published, and based on these results, people in urban areas spend on an average about 20 per cent of their income on 'food and beverages'. On the expenditure side, 'food and beverages' constitute 31.2 per cent share in total consumption expenditure.

\section{Macro food security}

To address the issue of macro food security, we analyse the trends in food and agricultural production in selected countries for the period 1991-2002 in total and per capita terms. Trends in production, imports and exports of total cereals, rice, coarse grains, and roots and tubers are reported. Import dependence and the degree of globalization in cereals, wheat, and rice are determined for each of the selected countries.

\subsection{Trends in food and agricultural production}

Total and per capita food and agricultural production indices are presented in Table 2 for the period 1991-2002 at base year 1989-91 values. The period is divided into four trienniums: 1991-93, 1994-96, 1997-99, and 2000-02. The figure for each triennium 
presents the average for three years. Oceania includes Australia, New Zealand, and the South Pacific Islands.

In Asia total and per capita food and agricultural production increased at a slower rate during the trienniums 1991-93 to 2000-02. Increases in food production were much higher than expansion of agricultural production. Similarly, increases in per capita food production were also higher than increases in agricultural production.

Table 2

Food and agriculture production indices, 1991-2002

(Base 1989-91 = 100)

\begin{tabular}{|c|c|c|c|c|c|c|c|}
\hline \multirow[b]{3}{*}{ Country } & \multirow[b]{3}{*}{ 1991-93 } & \multirow[b]{3}{*}{ 1994-96 } & \multirow[b]{3}{*}{ 1997-99 } & \multirow[b]{3}{*}{ 2000-02 } & \multicolumn{3}{|c|}{ Change between trienniums (\%) } \\
\hline & & & & & $1991-93$ to & $1994-96$ to & $1997-99$ to \\
\hline & & & & & 1994-96 & 1997-99 & $2000-02$ \\
\hline \multicolumn{8}{|l|}{ Total food production } \\
\hline Asia & 110.9 & 128.2 & 143.9 & 156.7 & 15.6 & 12.2 & 8.9 \\
\hline Oceania & 107.1 & 117.3 & 133.9 & 136.6 & 9.5 & 14.1 & 2.0 \\
\hline Fiji Islands & 95.8 & 104.0 & 93.8 & 96.8 & 8.5 & -9.8 & 3.2 \\
\hline Papua New Guinea & 106.1 & 110.7 & 118.2 & 124.3 & 4.3 & 6.8 & 5.2 \\
\hline Solomon Islands & 106.7 & 118.9 & 134.8 & 150.7 & 11.4 & 13.4 & 11.8 \\
\hline Tonga & 108.5 & 97.3 & 95.3 & 97.5 & -10.4 & -2.0 & 2.3 \\
\hline Vanuatu & 97.7 & 102.4 & 117.9 & 90.6 & 4.8 & 15.2 & -23.2 \\
\hline \multicolumn{8}{|c|}{ Total agriculture production } \\
\hline Asia & 111.0 & 127.3 & 141.9 & 153.9 & 14.7 & 11.5 & 8.4 \\
\hline Oceania & 104.3 & 109.3 & 123.5 & 124.0 & 4.8 & 13.1 & 0.4 \\
\hline Fiji Islands & 95.8 & 103.8 & 93.6 & 96.7 & 8.3 & -9.9 & 3.3 \\
\hline Papua New Guinea & 105.0 & 110.2 & 119.0 & 124.0 & 5.0 & 8.0 & 4.1 \\
\hline Solomon Islands & 106.7 & 118.8 & 134.6 & 150.6 & 11.4 & 13.3 & 11.8 \\
\hline Tonga & 108.5 & 97.3 & 95.3 & 97.5 & -10.4 & -2.1 & 2.3 \\
\hline Vanuatu & 97.7 & 102.4 & 117.9 & 90.7 & 4.8 & 15.2 & -23.1 \\
\hline \multicolumn{8}{|c|}{ Per capita food production } \\
\hline Asia & 105.8 & 116.0 & 124.7 & 130.4 & 9.7 & 7.5 & 4.6 \\
\hline Oceania & 103.7 & 108.3 & 118.6 & 116.4 & 4.5 & 9.4 & -1.8 \\
\hline Fiji Islands & 94.0 & 98.2 & 85.3 & 85.2 & 4.4 & -13.1 & -0.1 \\
\hline Papua New Guinea & 100.7 & 97.3 & 96.8 & 95.1 & -3.4 & -0.5 & -1.7 \\
\hline Solomon Islands & 100.0 & 100.4 & 102.8 & 103.9 & 0.4 & 2.4 & 1.0 \\
\hline Tonga & 107.8 & 95.7 & 92.7 & 93.9 & -11.2 & -3.1 & 1.3 \\
\hline Vanuatu & 92.4 & 89.1 & 94.5 & 67.3 & -3.6 & 6.1 & -28.8 \\
\hline \multicolumn{8}{|c|}{ Per capita agriculture production } \\
\hline Asia & 105.8 & 115.1 & 123.0 & 128.1 & 8.8 & 6.8 & 4.1 \\
\hline Oceania & 101.0 & 100.9 & 109.4 & 105.6 & -0.1 & 8.4 & -3.4 \\
\hline Fiji Islands & 94.0 & 97.9 & 85.1 & 85.2 & 4.2 & -13.1 & 0.0 \\
\hline Papua New Guinea & 99.6 & 96.9 & 97.4 & 94.9 & -2.7 & 0.5 & -2.6 \\
\hline Solomon Islands & 100.0 & 100.4 & 102.7 & 103.8 & 0.4 & 2.3 & 1.0 \\
\hline Tonga & 107.8 & 95.6 & 92.7 & 93.9 & -11.3 & -3.1 & 1.3 \\
\hline Vanuatu & 92.4 & 89.1 & 94.5 & 67.3 & -3.6 & 6.1 & -28.8 \\
\hline
\end{tabular}

Notes: Oceania includes Australia, New Zealand, and the South Pacific Islands.

Triennium is the average figure for three years.

Source: Computed from FAO data (2004). 
In most Pacific Island countries, the performance both in food and agricultural production has been poor compared with the performance in Asia. No clear-cut trend is observed in either the total or per capita production between trienniums. In 1997-99 in the Fiji Islands, per capita food production declined by 13 per cent over the previous triennium; Papua New Guinea shows a continuous decline in food production over the trienniums. Tonga and Vanuatu also show declines in per capita food production.

Table 3 presents the production of total cereals, wheat, rice, course grains, and roots and tubers in metric tonnes. In most Pacific Island countries, cereals are imported and net imports have increased during 1991-2002. Fiji re-exports cereals after importing from overseas to other islands in the Pacific region. Although Fiji has a potential to produce rice, its production declined from 29,000 to 14,000 tons during the triennium period, mainly because of the withdrawal of government subsidies in terms of farm inputs and technical advice, labour shortages, expiry of land leases, deregulation of the market, decreasing profits, as well as the population's preference for consuming imported rice. Furthermore, imported rice is cheaper than locally produced rice. Some rice is, however, produced at the subsistence level for home consumption. Government policy on rice production has been inconsistent, and recently, the government started the rice revitalization programme for enhancing production of paddy for local consumption.

Kakazu (1994) computes the productivity of land in terms of per-hectare dollar sales value for Fijian production of rice and sugarcane. Both products were valued in terms of world prices, namely the import price for rice and the export price for sugarcane. Sugarcane production was 2.5 times more productive per unit of resource used than rice production in 1971, and this increased to 3 times in 1975; and 4.2 times in 1980.

\subsection{Import dependence and degree of globalization in cereals}

The data on production, net imports (imports minus exports), and consumption of total cereals, wheat flour, and rice for the four trienniums are presented in Table 4. The degree of import dependence is calculated in terms of net imports as a percentage of domestic consumption (production plus net imports), and ranges from zero to 100 per cent. The degree of globalization is an indicator of country's linkage with international markets and is calculated as a ratio of the sum of imports and exports to domestic production. This ratio measures the degree of globalization per unit of domestic production. Thus the ratio would be meaningless if there is no production and is indicated in Table 4 with a dash $(-)$. When there is a certain amount of production and trade is high, then the ratio would be greater. For example, a ratio of 15 indicates that trade in food production is 15 times greater than domestic production. The main observations from these results emerge as follows:

i) Cook Islands, Samoa, and Tonga are a 100 per cent dependent on imports for cereals.

ii) Cereals import dependency for the Fiji Islands has increased from 79 to 90 per cent during the triennium 1991-93 to 2000-02. This is mainly due to the 50 per cent decline in rice production, dropping from 29,000 to 14,000 tons.

iii) Import dependency has slightly declined in Papua New Guinea (from 99 to 97 per cent) but increased in Solomon Islands (91 to 95 per cent) during the period. 
Table 3

Production, imports and exports of cereals, roots and tubers (in 100 metric tons)

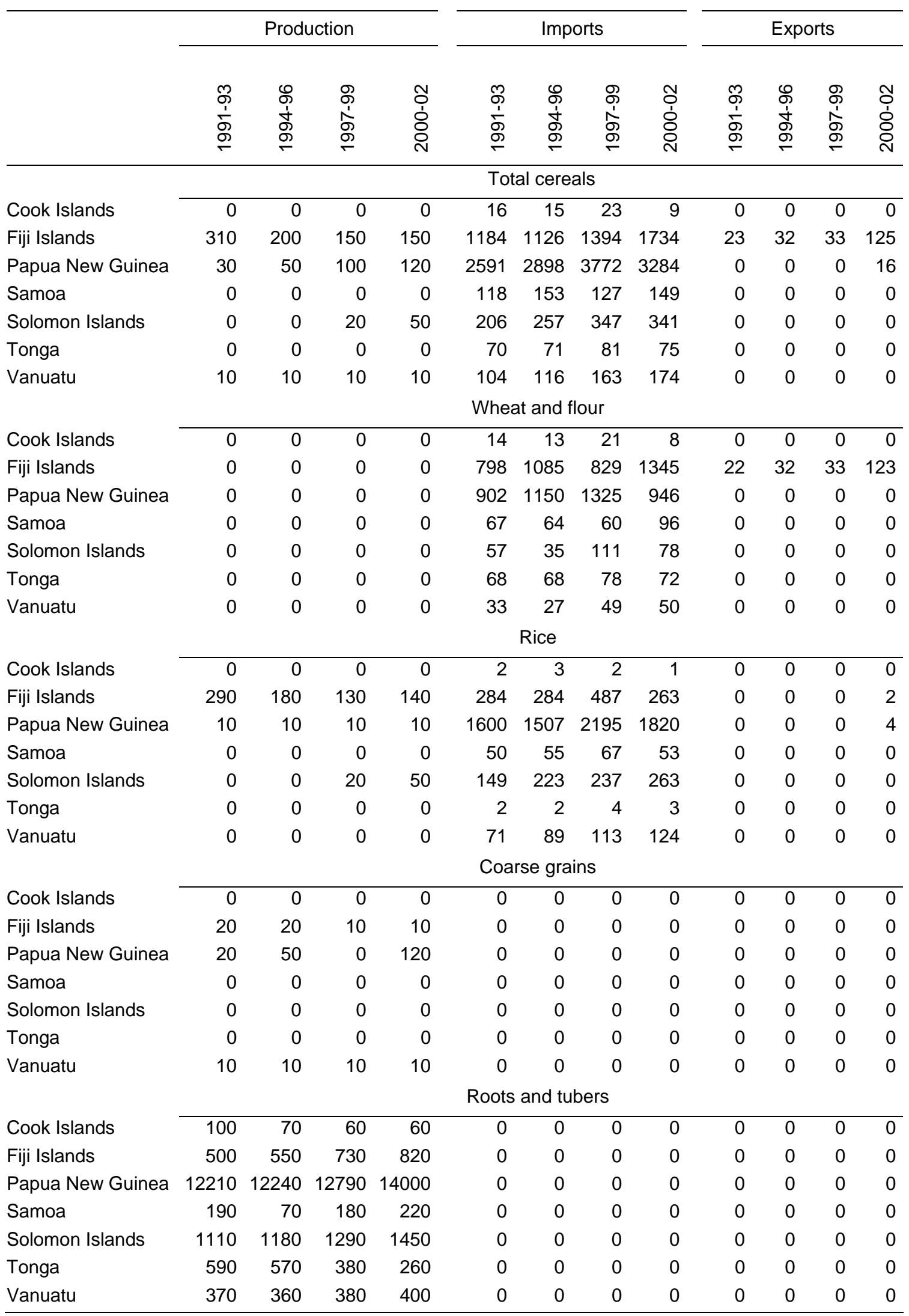

Source: Computed from FAO (2004), accessed on internet website. 
Table 4

Import dependence on cereals, and the degree of globalization, 1991-2002

\begin{tabular}{|c|c|c|c|c|c|c|c|c|c|c|c|c|c|c|c|c|c|c|c|c|}
\hline \multirow[b]{2}{*}{ Country } & \multicolumn{4}{|c|}{ Production ('00 tons) } & \multicolumn{4}{|c|}{ Net imports ('00 tons) } & \multicolumn{4}{|c|}{ Consumption ('00 tons) } & \multicolumn{4}{|c|}{ Import dependence (\%) } & \multicolumn{4}{|c|}{ Degree of globalization } \\
\hline & 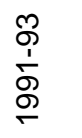 & 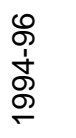 & 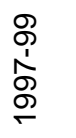 & $\begin{array}{l}\text { ㅇ } \\
\text { ○े } \\
\text { ठ্ } \\
\text { N }\end{array}$ & 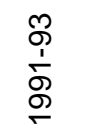 & 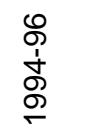 & 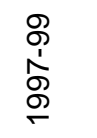 & $\begin{array}{l}\text { ㅇ } \\
\text { రి } \\
\text { రి }\end{array}$ & 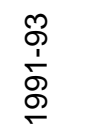 & 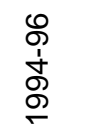 & 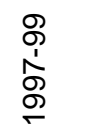 & 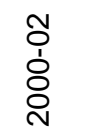 & $\begin{array}{l}\text { m } \\
\stackrel{1}{1} \\
\stackrel{-}{S} \\
\stackrel{-}{-}\end{array}$ & 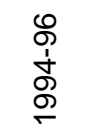 & 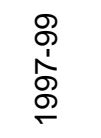 & 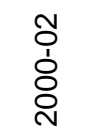 & 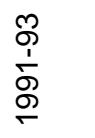 & 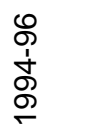 & 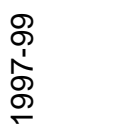 & 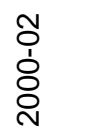 \\
\hline \multicolumn{21}{|c|}{ Total cereals } \\
\hline Cook Islands & 0 & 0 & 0 & 0 & 16 & 15 & 23 & 9 & 16 & 15 & 23 & 9 & 100.0 & 100.0 & 100.0 & 100.0 & - & - & - & - \\
\hline Fiji Islands & 310 & 200 & 150 & 150 & 1162 & 1427 & 1362 & 1609 & 1472 & 1293 & 1512 & 1759 & 78.9 & 84.5 & 90.1 & 91.5 & 3.9 & 7.5 & 9.5 & 12.4 \\
\hline Papua New Guinea & 30 & 50 & 100 & 120 & 2591 & 2898 & 3772 & 3268 & 2621 & 2948 & 3872 & 3388 & 98.9 & 98.3 & 97.4 & 96.5 & 86.4 & 58.0 & 37.7 & 27.5 \\
\hline Samoa & 0 & 0 & 0 & 0 & 118 & 153 & 127 & 149 & 118 & 153 & 127 & 149 & 100.0 & 100.0 & 100.0 & 100.0 & - & - & - & - \\
\hline Solomon Islands & 0 & 0 & 20 & 50 & 206 & 257 & 347 & 341 & 206 & 257 & 367 & 391 & 100.0 & 100.0 & 94.6 & 87.2 & - & - & 17.4 & 6.8 \\
\hline Tonga & 0 & 0 & 0 & 0 & 70 & 71 & 81 & 75 & 70 & 71 & 81 & 75 & 100.0 & 100.0 & 100.0 & 100.0 & - & - & - & - \\
\hline Vanuatu & 10 & 10 & 10 & 10 & 104 & 116 & 163 & 174 & 114 & 126 & 173 & 184 & 91.2 & 92.1 & 94.2 & 94.6 & 10.4 & 11.6 & 16.3 & 17.4 \\
\hline \multicolumn{21}{|c|}{ Wheat \& flour } \\
\hline Cook Islands & 0 & 0 & 0 & 0 & 14 & 13 & 21 & 8 & 14 & 13 & 21 & 8 & 100.0 & 100.0 & 100.0 & 100.0 & - & - & - & - \\
\hline Fiji Islands & 0 & 0 & 0 & 0 & 798 & 1053 & 796 & 1222 & 776 & 1053 & 796 & 1222 & 100.0 & 100.0 & 100.0 & 100.0 & - & - & - & - \\
\hline Papua New Guinea & 0 & 0 & 0 & 0 & 902 & 1150 & 1325 & 946 & 902 & 1150 & 1325 & 946 & 100.0 & 100.0 & 100.0 & 100.0 & - & - & - & - \\
\hline Samoa & 0 & 0 & 0 & 0 & 67 & 64 & 60 & 96 & 67 & 64 & 60 & 96 & 100.0 & 100.0 & 100.0 & 100.0 & - & - & - & - \\
\hline Solomon Islands & 0 & 0 & 0 & 0 & 57 & 35 & 111 & 78 & 57 & 35 & 111 & 78 & 100.0 & 100.0 & 100.0 & 100.0 & - & - & - & - \\
\hline Tonga & 0 & 0 & 0 & 0 & 68 & 68 & 78 & 72 & 68 & 68 & 78 & 72 & 100.0 & 100.0 & 100.0 & 100.0 & - & - & - & - \\
\hline Vanuatu & 0 & 0 & 0 & 0 & 33 & 27 & 49 & 50 & 33 & 27 & 49 & 50 & 100.0 & 100.0 & 100.0 & 100.0 & - & - & - & - \\
\hline \multicolumn{21}{|c|}{ Rice } \\
\hline Cook Islands & 0 & 0 & 0 & 0 & 2 & 3 & 2 & 1 & 2 & 3 & 2 & 1 & 100.0 & 100.0 & 100.0 & 100.0 & - & - & - & - \\
\hline Fiji Islands & 290 & 180 & 130 & 140 & 283 & 284 & 487 & 261 & 573 & 464 & 617 & 401 & 49.4 & 61.2 & 78.9 & 65.1 & 1.0 & 0.6 & 3.7 & 1.9 \\
\hline Papua New Guinea & 10 & 10 & 10 & 10 & 1600 & 1507 & 2195 & 1817 & 1610 & 1517 & 2205 & 1827 & 99.4 & 99.3 & 99.5 & 99.5 & 160 & 150.7 & 219.5 & 182.4 \\
\hline Samoa & 0 & 0 & 0 & 0 & 50 & 55 & 67 & 53 & 50 & 55 & 67 & 53 & 100.0 & 100.0 & 100.0 & 100.0 & - & - & - & - \\
\hline Solomon Islands & 0 & 0 & 20 & 50 & 149 & 223 & 237 & 263 & 149 & 223 & 257 & 313 & 100.0 & 100.0 & 92.2 & 84.0 & - & - & 11.9 & 5.3 \\
\hline Tonga & 0 & 0 & 0 & 0 & 2 & 2 & 4 & 3 & 2 & 2 & 4 & 3 & 100.0 & 100.0 & 100.0 & 100.0 & - & - & - & - \\
\hline Vanuatu & 0 & 0 & 0 & 0 & 71 & 89 & 113 & 124 & 71 & 89 & 113 & 124 & 100.0 & 100.0 & 100.0 & 100.0 & - & - & - & - \\
\hline
\end{tabular}

Note: Triennium is an average figure of three years.

Source: Computed from FAO (2004). 
iv) All selected islands are completely dependent on imported wheat flour.

v) Import dependency for rice is noted in the Cook Islands, Samoa, Tonga, Vanuatu, and Fiji, ranging between 65-100 per cent.

The degree of globalization in cereals has increased fourfold for Fiji Islands, while for Vanuatu the increase was about one and half times during 1991-2002. For Papua New Guinea, the extent of globalization decreased by three times during the period.

\section{Trade in food products and export earnings}

As mentioned earlier, small island countries concentrate on the production of a few commodities for exports to earn foreign exchange. This section deals with the contribution of agricultural and food products in total exports and imports, and attempts to determine whether a country has the capacity to generate export earnings to finance its food imports.

\subsection{Main exports and subsistence sector}

The relative importance of foreign trade for the selected Pacific Island countries in 2003 is shown in Table 5. The degree of openness (dependence on foreign markets) is generally measured by the trade-to-GDP ratio (trade covering both exports and imports). The smallest ratio is 47 per cent for Samoa and Vanuatu, while the Fiji Islands and Tonga have ratios of 75 to 79 per cent and are heavily dependent on foreign trade. Papua New Guinea has the highest degree of trade openness of 130 per cent.

Due to narrow resource base and production conditions, small islands concentrate on a few primary commodities. Diversification is limited, making small islands highly dependent on imports of food and nonfood items, and exports of only a few commodities. Table 5 presents the shares of the primary and three principal commodities in total export earnings in the selected island economies in 2003. Main export products include fruits and vegetables, fish and seafood, sugar, copra, meat, timber, garments, and mining products. The primary export commodity-fish and seafood in the Cook Islands, timber in Solomon Islands, squash in Tonga-accounts for 40 to 67 per cent of total export earnings. In Fiji, sugar is the main foreign export earner and contributed more than 40 per cent of total export earnings until the 1990s. Recently, the contribution of sugar in export earnings has decreased to 18 per cent and earnings from garments reached 20 per cent, mainly reflecting the decrease in sugarcane production in recent years. Three main export commodities accounted for 74 to 93 per cent of total exports in the selected island countries. The exception is Fiji where it was 45 per cent. Fiji is relatively more diversified in production and exports than the other countries.

Most of the Pacific Island economies are based on dual systems with a small commercialized sector coexisting with a large subsistence sector. Subsistence activities include the production and processing of foodstuffs, construction activity, furniture making and traditional crafts. A wide range of agricultural products are grown at subsistence level for home consumption such as cassava, taro, coconuts, breadfruits, 
Table 5

Relative importance of foreign trade of the Pacific Islands, 2003

\begin{tabular}{|c|c|c|c|c|c|c|c|c|c|c|}
\hline \multirow[b]{2}{*}{ Country } & \multirow[b]{2}{*}{ GDP } & \multirow[b]{2}{*}{ Total exports } & \multirow[b]{2}{*}{ Total imports } & \multirow[b]{2}{*}{$\begin{array}{c}\text { Degree of } \\
\text { openness \% }\end{array}$} & \multicolumn{2}{|c|}{ As \% of GDP } & \multicolumn{2}{|c|}{ Share of exports \% of } & & \multirow[b]{2}{*}{ Commodity } \\
\hline & & & & & Exports \% & Imports \% & $\begin{array}{c}\text { primary } \\
\text { commodity }\end{array}$ & $\begin{array}{c}3 \text { main } \\
\text { commodities }\end{array}$ & & \\
\hline \multirow{3}{*}{$\begin{array}{l}\text { Cook Islands } \\
\text { NZ\$ (million) }\end{array}$} & 238.6 & 14.6 & 121.0 & 56.8 & 6.1 & 50.7 & 56.8 & 80.1 & 1. & Fish \& seafood (8.3) \\
\hline & & & & & & & & & 2. & Pearls (2.8) \\
\hline & & & & & & & & & 3. & Fruits \& vegetables (0.6) \\
\hline Fiji Island & $4,674.0$ & 1,273.1 & $2,214.6$ & 74.6 & 27.2 & 47.4 & 19.8 & 44.6 & 1. & Garmets (252.7) \\
\hline \multirow[t]{2}{*}{ F\$ (million) } & & & & & & & & & 2. & Sugar (230.7) \\
\hline & & & & & & & & & 3. & Fish \& seafood (85.0) \\
\hline \multirow{3}{*}{$\begin{array}{l}\text { Papua New Guinea } \\
\text { Kina \$ (million) }\end{array}$} & $9,254.7$ & $7,842.0$ & $4,231.0$ & 130.5 & 84.7 & 45.7 & 35.8 & 74.7 & 1. & Gold (2811) \\
\hline & & & & & & & & & 2. & Crude petroleum (1632) \\
\hline & & & & & & & & & 3. & Copper (1415) \\
\hline \multirow{3}{*}{$\begin{array}{l}\text { Samoa } \\
\text { Tala \$ (million) }\end{array}$} & 945.3 & 44.3 & 407.0 & 47.7 & 4.7 & 43.1 & 35.7 & 74.3 & 1. & Fresh fish (15.8) \\
\hline & & & & & & & & & 2. & Garmets (13.3) \\
\hline & & & & & & & & & 3. & Beer (3.8) \\
\hline \multirow{3}{*}{$\begin{array}{l}\text { Solomon Islands } \\
\text { SI \$ (million) }\end{array}$} & $1,588.3$ & 557.0 & 507.0 & 67.0 & 35.1 & 31.9 & 66.7 & 92.9 & 1. & Timber (371.4) \\
\hline & & & & & & & & & 2. & Fish \& seafood (92.9) \\
\hline & & & & & & & & & 3. & Cocoa (53.2) \\
\hline \multirow{3}{*}{$\begin{array}{l}\text { Tonga } \\
\text { Pa'anga \$ (million) }\end{array}$} & 295.1 & 34.9 & 199.2 & 79.3 & 11.8 & 67.5 & 40.4 & 77.4 & 1. & Squash (14.1) \\
\hline & & & & & & & & & 2. & Fish (12.4) \\
\hline & & & & & & & & & 3. & Vanila beans $(0.5)$ \\
\hline \multirow{3}{*}{$\begin{array}{l}\text { Vanuatu } \\
\text { Vatu \$ (million) }\end{array}$} & $33,820.0$ & $3,252.0$ & $12,702.0$ & 47.2 & 9.6 & 37.6 & - & - & 1. & Beef \\
\hline & & & & & & & & & 2. & Copra \\
\hline & & & & & & & & & 3. & Timber \\
\hline
\end{tabular}

Source: Computed from ADB data (2005). 
fish, pork, poultry, livestock and forestry products. Recent estimates of the subsistence component for the Fiji Islands for 2002 was 6 per cent of GDP and 37 per cent of output of the agriculture, fisheries, and forestry sector. This demonstrates that the subsistence sector contributes at least one-third of the output of the agriculture, fisheries and forestry sector. Other island countries also have large subsistence agricultural sectors, and these have played an important role in providing food security, particularly in the rural areas.

\subsection{Merchandise trade in food products}

All the selected island countries, except Papua New Guinea, show increasing trade deficits (negative net exports) during 1991-93 to 2000-02 (Table 6). In agricultural products, the Fiji Islands, and Solomon Islands had trade surpluses, while Cook Islands, Samoa, and Tonga were trade-deficit countries. In food trade, Fiji and Solomon Islands had trade surpluses while others showed deficits in trade.

The share of agriculture and food in trade is given in Table 7. It is evident from the table that the share of agriculture (including fisheries products) in total export earnings declined from 21 to 3 per cent in the Cook Islands, 47 to 36 per cent in the Fiji Islands, 92 to 77 per cent in Samoa, 84 to 76 per cent in Tonga, and 59 to 53 per cent in Vanuatu during the trienniums 1991-93 to 2000-02. The contribution of agricultural export earnings increased only in Solomon Islands.

Food imports constituted between 9-29 per cent of total import expenditure in selected island countries. The share of cereals in food imports was 23 per cent in the Fiji Islands, 40 per cent in Papua New Guinea, 9 per cent in Samoa, 57 per cent in Solomon Islands, 10 per cent in Tonga, and 31 per cent in Vanuatu during the recent triennium 2000-02.

\subsection{Self-reliance in food products}

There are two main ways to achieve food security at national level: food self-sufficiency, and building capacity for food imports. A large number of countries pursue a strategy of food self-sufficiency and meet most of their consumption needs from domestic supply, thus minimizing food imports. Other countries try to fulfil their consumption needs by maintaining domestic production and building capacity by generating export earnings to import food for achieving self-reliance. Due to resource constraints, small countries generally produce only a few food items and import the rest of their consumption requirements.

How are food imports financed? Does a country have the capacity to pay for its imports? The ratio of expenditure on food imports to export earnings from agriculture and from total exports is an indicator of the capacity of an economy for achieving self-reliance in food products over a given period of time (Chand 2005). Self-reliance is a dynamic concept. An increasing trend in this ratio shows deterioration in self-reliance and decreasing trend indicates improvement in self-reliance. For example, if the ratio is 1.45 in period one and 2.30 in period two, this implies that imports require 1.45 times the resources earned from exports in period one and 2.30 times in period two, thus reflecting a deterioration in self-reliance. Food self-reliance for the Pacific Island states in terms of agricultural exports and total commodity export earnings is given in Table 7. 
Table 6

Merchandise trade, value of imports and exports of agriculture and food products (US $\$ 100,000)$ Trienniums 1991 to 2002

\begin{tabular}{|c|c|c|c|c|c|c|c|c|c|c|c|c|}
\hline \multirow[b]{2}{*}{ Country } & \multicolumn{4}{|c|}{ Imports } & \multicolumn{4}{|c|}{ Exports } & \multicolumn{4}{|c|}{ Net exports } \\
\hline & $1991-93$ & $1994-96$ & 1997-99 & $2000-02$ & 1991-93 & $1994-96$ & $1997-99$ & $2000-02$ & 1991-93 & $1994-96$ & $1997-99$ & $2000-02$ \\
\hline \multicolumn{13}{|c|}{ Total merchandise trade } \\
\hline Cook Islands & 554 & 842 & 739 & 1084 & 42 & 40 & 57 & 157 & -512 & -802 & -682 & -927 \\
\hline Fiji Islands & 6677 & 8934 & 8634 & 8427 & 4481 & 6377 & 5809 & 5538 & -2196 & -2557 & -2825 & -2889 \\
\hline Papua New Guinea & 13378 & 13714 & 12184 & 10115 & 20090 & 26149 & 19730 & 17927 & 6712 & 12435 & 7546 & 7812 \\
\hline Samoa & 1039 & 904 & 1043 & 1235 & 74 & 74 & 172 & 142 & -965 & -830 & -871 & -1093 \\
\hline Solomon Islands & 1196 & 1532 & 1734 & 1119 & 1056 & 1576 & 1527 & 847 & -140 & 44 & -207 & -272 \\
\hline Tonga & 635 & 722 & 697 & 798 & 155 & 132 & 101 & 223 & -480 & -590 & -596 & -575 \\
\hline Vanuatu & 800 & 949 & 950 & 930 & 215 & 278 & 317 & 224 & -585 & -671 & -633 & -706 \\
\hline \multicolumn{13}{|c|}{ Total agriculture products, including fish and fishery products } \\
\hline Cook Islands & 112 & 118 & 124 & 117 & 9 & 10 & 7 & 4 & -103 & -108 & -117 & -113 \\
\hline Fiji Islands & 1268 & 1463 & 1504 & 1359 & 2100 & 2811 & 2134 & 1995 & 832 & 1348 & 630 & 636 \\
\hline Papua New Guinea & 2538 & 2751 & 2212 & 2073 & 2467 & 4090 & 5067 & 2051 & -71 & 1339 & 2855 & -22 \\
\hline Samoa & 231 & 287 & 246 & 302 & 68 & 54 & 163 & 110 & -163 & -233 & -83 & -192 \\
\hline Solomon Islands & 177 & 201 & 211 & 212 & 571 & 657 & 520 & 523 & 394 & 456 & 309 & 311 \\
\hline Tonga & 169 & 237 & 229 & 206 & 130 & 116 & 93 & 170 & -39 & -121 & -136 & -36 \\
\hline Vanuatu & 169 & 202 & 212 & 172 & 126 & 243 & 219 & 119 & -43 & 41 & 7 & -53 \\
\hline \multicolumn{13}{|c|}{ Food,including fish and fishery products } \\
\hline Cook Islands & 80 & 87 & 97 & 94 & 7 & 8 & 7 & 4 & -73 & -79 & -90 & -90 \\
\hline Fiji Islands & 1140 & 1285 & 1324 & 1219 & 2072 & 2766 & 1960 & 1840 & 932 & 1481 & 636 & 621 \\
\hline Papua New Guinea & 2218 & 2424 & 1943 & 1846 & 1479 & 2212 & 2796 & 2050 & -739 & -212 & 853 & 204 \\
\hline Samoa & 205 & 262 & 228 & 289 & 59 & 45 & 152 & 100 & -146 & -217 & -76 & -189 \\
\hline Solomon Islands & 140 & 164 & 178 & 180 & 559 & 646 & 713 & 511 & 419 & 482 & 535 & 331 \\
\hline Tonga & 132 & 185 & 186 & 171 & 127 & 108 & 80 & 161 & -5 & -77 & -106 & -10 \\
\hline Vanuatu & 127 & 154 & 152 & 140 & 111 & 233 & 207 & 105 & -16 & 79 & 55 & -35 \\
\hline
\end{tabular}

Note: Triennium is an average figure of three years.

Sources: FAO (Trade Commerce Yearbook, various issues) and FAO (Yearbook 2002). 
Table 7

Share of agriculture and food in trade and financing of food imports Trienniums 1991 to 2002

\begin{tabular}{|c|c|c|c|c|}
\hline Country & 1991-93 & $1994-96$ & 1997-99 & $2000-02$ \\
\hline \multicolumn{5}{|c|}{ Agricultural exports, including fish and fishery products in total exports (\%) } \\
\hline Cook Islands & 21.42 & 25.00 & 12.28 & 2.55 \\
\hline Fiji Islands & 46.86 & 44.08 & 36.74 & 36.02 \\
\hline Papua New Guinea & 12.28 & 15.64 & 25.68 & 11.44 \\
\hline Samoa & 91.89 & 72.97 & 94.77 & 77.46 \\
\hline Solomon Islands & 54.07 & 41.69 & 34.05 & 61.75 \\
\hline Tonga & 83.87 & 87.88 & 92.08 & 76.23 \\
\hline Vanuatu & 58.60 & 87.41 & 69.09 & 53.13 \\
\hline \multicolumn{5}{|c|}{ Food imports including fish and fishery products in total imports (\%) } \\
\hline Cook Islands & 14.44 & 10.33 & 13.13 & 8.67 \\
\hline Fiji Islands & 17.07 & 14.38 & 15.33 & 14.47 \\
\hline Papua New Guinea & 16.58 & 17.68 & 15.95 & 18.25 \\
\hline Samoa & 19.73 & 28.98 & 21.86 & 23.40 \\
\hline Solomon Islands & 11.71 & 10.70 & 10.27 & 16.08 \\
\hline Tonga & 20.79 & 25.62 & 26.69 & 21.43 \\
\hline Vanuatu & 15.88 & 16.23 & 16.08 & 15.05 \\
\hline \multicolumn{5}{|c|}{ Cereals imports in food, including fish and fishery products (\%) } \\
\hline Cook Islands & 6.75 & 7.01 & 6.29 & 4.36 \\
\hline Fiji Islands & 21.03 & 22.82 & 24.40 & 22.95 \\
\hline Papua New Guinea & 31.51 & 31.14 & 46.68 & 40.05 \\
\hline Samoa & 15.85 & 15.19 & 9.78 & 8.55 \\
\hline Solomon Islands & 54.00 & 53.48 & 66.12 & 56.50 \\
\hline Tonga & 13.64 & 11.30 & 10.97 & 10.35 \\
\hline Vanuatu & 33.86 & 32.34 & 36.25 & 31.21 \\
\hline \multicolumn{5}{|c|}{ Agriculture exports needed to finance food imports, self-reliance using agricultural exports } \\
\hline Cook Islands & 8.89 & 8.70 & 13.86 & 23.50 \\
\hline Fiji Islands & 0.54 & 0.46 & 0.62 & 0.61 \\
\hline Papua New Guinea & 0.90 & 0.59 & 0.38 & 0.90 \\
\hline Samoa & 3.01 & 4.85 & 1.40 & 2.63 \\
\hline Solomon Islands & 0.25 & 0.25 & 0.34 & 0.34 \\
\hline Tonga & 1.02 & 1.59 & 2.00 & 1.01 \\
\hline Vanuatu & 1.01 & 0.63 & 0.69 & 1.18 \\
\hline \multicolumn{5}{|c|}{ Total exports needed to finance food imports, self-reliance using total exports } \\
\hline Cook Islands & 1.90 & 2.18 & 1.70 & 0.60 \\
\hline Fiji Islands & 0.25 & 0.20 & 0.23 & 0.22 \\
\hline Papua New Guinea & 0.11 & 0.09 & 0.10 & 0.45 \\
\hline Samoa & 2.77 & 3.54 & 1.32 & 2.04 \\
\hline Solomon Islands & 0.13 & 0.10 & 0.12 & 0.21 \\
\hline Tonga & 0.85 & 1.40 & 1.84 & 0.77 \\
\hline Vanuatu & 0.59 & 0.55 & 0.48 & 0.63 \\
\hline
\end{tabular}

Source: Computed from Table 6. 
Fiji used about half of its resources earned from agricultural exports on food imports in 1991-93 and this increased to 61 per cent in 2000-02, indicating a decrease in self-reliance during the period. In Fiji, sugar and garments are the major export earners and a further deterioration can be expected when sugar is sold on the open world market after the expiry of its preferential price agreement with the European Union in 2007. Similarly, earnings from garments depend on the access to markets and on agreements with such importing countries as Australia, New Zealand and the USA. Tonga and Vanuatu exhibit a decrease when self-reliance is measured against export earnings from agriculture. Similar trends are also observed when self-reliance is measured in terms of total export earnings. The Cook Islands show a deterioration in self-reliance in terms of earnings from agricultural exports but an improvement in total export earnings during recent years.

\section{$5 \quad$ Food distribution system}

An efficient marketing system provides physical access to food, thus reducing hunger and improving food security. In rural areas in the Pacific, most people produce subsistence food (roots and tubers), and fruits and vegetables on their farms and backyards. In the Fiji Islands, farmers also grow rice for subsistence. People fish and harvest seafood. Food is also shared, as the customary practice dictates. Surplus food is sold in the villages for cash for purchasing other food items such as sugar, salt, biscuits, tea, coffee, oil, tinned food, etc. In urban areas, farmers bring agricultural products (cassava, taro, kumala, coconuts, papaya, banana, lemons, breadfruits, and vegetables) from the villages to urban markets. Products are delivered to market vendors in designated areas, but also to city supermarkets. Farmers also sell their products themselves.

Certain foods - rice, wheat flour, oil, dairy products, meat, beverages and fruits-are imported with government-issued licenses. Importers deliver products to the supermarkets and shops. Similarly, farmers produce for export such products as cassava, taro, papaya, ginger, vegetables, and fish and deliver these to license holders, cooperatives, and firms for exports. Producers are advised on supply specifications. Exporters handle the grading and ascertain that quarantine requirements are observed.

In the South Pacific Islands, there is no government involvement in agricultural marketing. Farmers and business firms undertake the task of delivering food to shops and supermarkets, where consumers buy their food. In the Fiji Islands, a price and income board fixes the prices of some items such as rice, flour, oil, dairy products, etc., while the price for other products is determined by supply and demand.

\section{Household food security}

Macro food security does not adequately ensure food security at the household level. Domestic marketing systems and the government play an important role in converting macro food security into household security (Acharya 2002). Further, household food-security issues should be analysed within the given socioeconomic setting of the country's population. Table 8 shows key socioeconomic indicators with poverty 
estimates of selected Pacific Island economies. The following observations can be made from the data in the table.

i) Many islands are rural. In 1990 in Samoa, Solomon Islands, and Vanuatu, 79-86 per cent of the population was rural. There is steady outflow of people from rural to urban areas; for example, in the Fiji Islands, rural population decreased by 10 per cent from 58 to 48 per cent during 1990-2003.

ii) More than 47 per cent of the active male labourforce are engaged in the agricultural sector in most of the islands. Females also participate extensively in agricultural work, comprising, for instance, 84 per cent of the workforce in Papua New Guinea. This demonstrates the high dependency of the population on agriculture.

iii) The share of agriculture in GDP has declined in most islands at a steady rate during 1990-2002, following the pattern of other developing countries. This has increased the income disparity between agricultural and nonagricultural sectors.

iv) The economic performance of most south Pacific Island economies was poor during the second half of 1990s. The agricultural sector in the Fiji Islands has recorded a continuing negative growth in 1990, 1995 and 2000. Papua New Guinea and Solomon Islands also showed low and negative growth, and the poor performance of the agricultural sector has become a limiting factor for the growth of other sectors.

v) The per capita income of most small island economies, in comparison to the world average, is in the middle range. The per capita income in 2003 was US\$5570 in the Cook Islands, while it was US\$2169 in the Fiji Islands, US\$1509 in Samoa, US\$1348 in Tonga, and US\$1127 in Vanuatu. The lower per capita income of US\$541 to US\$661 in Papua New Guinea and Solomon Islands, respectively, is mainly due the higher rate of population growth. Per capita income increased in all selected Pacific Islands during the period 1990-2002. However, compared to some countries in Asia such as India, China, and Thailand, population growth has been considerably high in some Pacific Island economies. Annual population growth was 5 per cent in Papua New Guinea, 3.7 per cent in Solomon Islands, and 2.6 per cent in Vanuatu during 1995-2002 (Table 1).

vi) Gini coefficient is a measure of inequality in income distribution, derived from the Lorenz Curve. The coefficient has a maximum value of unity (absolute inequality) and a minimum of zero (absolute equality). The coefficient in Pacific Island countries ranges between 0.42 and 0.49 , showing that the distribution of income is excessively skewed compared to some countries in Asia and Africa.

To a large extent, economic access to food depends on the purchasing power of households in rural and urban areas. The data on poverty estimates for most small islands are not available. For some islands, the data are year specific and given at the national level instead of being decomposed into rural and urban households (Table 8). 
Table 8

Poverty estimates, rural population, employment and performance of agriculture sector in selected Pacific Island countries

\begin{tabular}{|c|c|c|c|c|c|c|c|}
\hline Country & $\begin{array}{l}\text { Cook } \\
\text { Islands }\end{array}$ & $\begin{array}{c}\text { Fiji } \\
\text { Islands }\end{array}$ & $\begin{array}{c}\text { Papua New } \\
\text { Guinea }\end{array}$ & Samoa & $\begin{array}{l}\text { Solomon } \\
\text { Islands }\end{array}$ & Tonga & Vanuatu \\
\hline Year & - & 1990 & 1996 & 2002 & - & 2001 & 1998 \\
\hline \multicolumn{8}{|l|}{ National poverty rates (\%) } \\
\hline National & - & 25.5 & 37.5 & 20.3 & - & 22.7 & - \\
\hline Urban & - & 27.6 & 16.1 & - & - & - & - \\
\hline Rural & - & 22.4 & 41.3 & - & - & - & - \\
\hline \multicolumn{8}{|l|}{$\begin{array}{l}\text { International poverty measure } \\
\text { below } \$ 1 \text { (PPP) per day }\end{array}$} \\
\hline Proportion of population (\%) & - & 25.0 & 24.6 & 5.5 & - & 4.0 & 40.0 \\
\hline Magnitude ('000) & - & 184.3 & 1023.4 & 9.8 & - & 4.0 & 72.8 \\
\hline Gini coefficient & - & 0.490 & 0.480 & 0.440 & - & 0.420 & - \\
\hline \multicolumn{8}{|l|}{ Per capita (US\$) } \\
\hline 1990 & - & 1832 & 873 & 935 & 627 & 1176 & 1033 \\
\hline 2002 & 5570 & 2169 & 541 & 1509 & 661 & 1348 & 1127 \\
\hline \multicolumn{8}{|c|}{ Rural population $\%$ of total population } \\
\hline 1990 & 42.1 & 58.4 & 85.0 & 78.7 & 85.5 & 68.7 & 81.3 \\
\hline 2003 & 29.8 & 48.3 & 86.8 & 77.7 & 83.5 & 66.6 & 78.0 \\
\hline \multicolumn{8}{|c|}{ Employment in agriculture (\%), 2000} \\
\hline Male & 15.0 & 47.0 & 71.0 & 73.0 & 43.9 & 53.0 & 69.0 \\
\hline Female & 6.0 & 28.0 & 84.0 & 67.0 & 50.8 & 1.0 & 80.0 \\
\hline \multicolumn{8}{|l|}{$\begin{array}{l}\text { Share of agriculture in GDP } \\
\text { (\% at current prices) }\end{array}$} \\
\hline 1990 & 21.2 & 22.2 & 29.0 & 23.0 & 45.5 & 34.7 & 20.7 \\
\hline 2002 & 11.9 & 15.9 & 33.1 & 15.3 & - & - & 15.6 \\
\hline \multicolumn{8}{|l|}{$\begin{array}{l}\text { Growth rate of output in agriculture } \\
\text { (\% p.a. at constant prices) }\end{array}$} \\
\hline 1990 & 13.2 & -4.6 & 2.2 & - & - & 3.9 & 15.5 \\
\hline 1995 & -2.5 & -3.2 & -0.1 & 12.7 & - & 0.3 & 2.9 \\
\hline 2000 & 0.1 & -0.9 & 2.1 & 0.1 & -16.3 & 10.8 & 7.4 \\
\hline 2002 & 9.4 & 2.2 & -4.1 & -6.3 & 5.1 & - & 1.7 \\
\hline
\end{tabular}

Notes: Percentage of rural population is obtained by subtracting the percentage of urban population from 100.

Share of agriculture in GDP for Fiji is calculated from the Bureau of Statistics (2004).

Employment figures for Solomon Islands are for 1990.

Source: ADB (2004).

In the Fiji Islands, the proportion of the people living below the poverty line of US\$1 (PPP) per day in 1990 was 25 per cent of the population, affecting 184,000 people. Poverty is more pronounced in the urban areas than rural areas. In 1996, the proportion of the population below the poverty line in Papua New Guinea was estimated at about 25 per cent, representing one million people. In Vanuatu, poverty in 1998 affected 40 per cent of the population, highest among the selected Pacific Island countries. Poverty was estimated to be the lowest in Samoa and Tonga, ranging between 4 to 5.5 per cent. In Fiji, the incidence of poverty as defined by basic costs, increased by 60 per cent 
between 1977 and 1990-91. Poverty was highly pronounced in urban areas due to the rise in food costs (Sharma 2004).

\section{Strategies to reduce food insecurity}

Macro food security that would ensure an adequate food supply for the small islands calls for a strategy consisting of the following. Total and per capita food and agricultural production have declined in most selected island countries during the 1990s. Population growth rate is, on average, between 2.5-5.0 per cent per annum in some countries and the performance of the agricultural sector is poor. It is imperative that productivity in the agricultural sector be increased through government investment in rural infrastructure, agricultural research and extension, irrigation, and appropriate price incentives to farmers.

In the Fiji Islands, there are some critical institutional constraints, which hinder the agricultural performance. Native Fijians have property rights to land, owning most of the agricultural land. These are leased to Indian farmers for cultivation for a fixed term with no certainty of renewal. Therefore, these farmers do not make much effort to increase productivity (Prasad and Tisdell 1996). Other constraints include the availability and cost of credit, technological adaptation, and rural infrastructure.

Fiji has the potential to grow rice in some parts of the island for supplementing imports for domestic consumption. Incentives are needed for the farmers in terms of technical advice, supply of farm inputs, improved varieties with irrigation facilities, milling arrangements, and a fair price. This would reduce Fiji's import dependence on rice and save foreign exchange.

i) Small islands are heavily dependent on wheat flour and rice. Private license holders should maintain adequate buffer stocks of cereals and other food stuffs, say, at least for one month in order to avoid delays in food supply due to adverse weather conditions.

ii) Central monetary authorities in small islands should have sufficient foreign exchange to import food products for at least three months. The Reserve Bank of Fiji has this provision.

iii) Governments should monitor food quality standards for domestic and imported food. This includes amendments in the existing Pure Food Acts regulations in terms of labelling, expiry date, nutrition contents, preservatives, colouring, artificial sweetening, etc. Currently, there are no provisions for regulating fish and fish products.

\subsection{Physical accessibility of food}

An efficient food marketing system can help to improve food security of both the poor food-producing farmers and food-insecure urban population. In Fiji, the external marketing of some agricultural products, namely sugar, tinned fish, and forestry products, has been organized effectively. A more serious problem is the internal marketing of fruits, vegetables, fish, and dairy products. For farmers in the villages, the absence of appropriate transport and storage facilities poses a serious problem for 
marketing their produce. Roads linking the entire village and periodic markets are not well developed. Furthermore, the islands are scattered and boat transport is used to deliver products, and delivery can be affected by cyclones and other unfavourable weather conditions. There is a great need to improve infrastructure, storage facilities and cooperative arrangements for handling food products (Sharma 2004). The Pacific Island countries need to invest resources in disaster risk management activities to minimize adverse effects in the long run. Measures for disaster preparedness include early warning systems, evacuation planning, buffer stocks of food, and other post-relief measures.

\subsection{Economic accessibility of food at household level}

Poverty is the main cause of food insecurity at the individual level. Thompson (1999) states that it is not enough to focus exclusively on agriculture to solve rural poverty. Off-farm employment opportunities need to be created, either within the rural communities or in the cities for increasing the purchasing power of people. These could include mat-making, handicrafts, farm-input supply, work in cottage industries. Timmer (1997) emphasizes that the growth process stimulated by a dynamic rural economy leads to rapid poverty alleviation, which in the context of public action to stabilize food prices, ensures food security.

Rural-urban migration is increasing at a rapid rate in some of the islands countries, namely Cook Islands, Fiji Islands, Solomon Islands, and Vanuatu. This may lead to an increase in urban poverty. Governments need to provide attractive opportunities in the rural areas to slow down urbanization. This requires larger investment in roads, communications, education, health care, and creation of employment opportunities. These investments in infrastructure and human capital are also important for successful agricultural development (Thompson 1999).

There is a strong communal fallback system in traditional Pacific societies that helps people in the provision of food. However, with the growing transition from an agrarian to an urban society, traditional support systems are weakening and food insecurity has increased.

Healthy diets and lifestyle need to be promoted to prevent non-communicable diseases in the islands. Malnutrition, especially in children, exists due to the lack of protein in the diet. Thus, dissemination efforts at promoting healthy diets are the key to improving the nutritional status and health of the population. The Fiji Plan of Action for nutrition was prepared in 1997 and is being implemented.

\section{Conclusions}

The small island countries of the South Pacific selected for this study are net importers of cereals. Import dependency for food increased over the period 1991-2002 due to a decline in per capita food production and a rapid rate of rural-urban migration. National food security is dependent on the continuation of subsistence farming and tapping ocean resources in conjunction with the on-going commercial farming of those crops in which Pacific Islands have a comparative advantage. In the Pacific Island states, there is little hunger of the type seen in some Asian and African countries. But because of the 
increase of population and urbanization, the demand for imported food items has grown. Currently export earnings from primary production can finance food imports in most of the island countries. However, the prices of main exported agricultural commodities are volatile in world markets and earnings could fall short of the requirements needed to finance the purchases of food from overseas. In the Fiji Islands, a large proportion of sugar exports is sold in the protected markets of Europe, which will end in 2007 and earnings could fall in a competitive world market. Increased productivity is crucial for improving agricultural performance through government investment in rural infrastructure, agricultural research and extension, irrigation and appropriate price incentives. Policies to promote agricultural growth should form a vital part of the strategy to reduce food insecurity. This would also help alleviate poverty. There is also a need to design appropriate disaster risk management programmes to minimize any adverse effects of natural disasters on the food supply.

\section{References}

Acharya, S. S. (2002). 'Towards Hunger Free Asia: Some Facts and Emerging Issues'. Paper presented at the Fourth Conference of Asian Society of Agricultural Economics. Alor Setar, Malaysia.

Asian Development Bank (ADB) (2004). Key Indicators, Poverty in Asia: Measurement, Estimates, and Prospects, vol. 35. Manila: ADB.

Asian Development Bank (ADB) (2005). Key Indicators. Manila: ADB.

Briguglio, L. (1995). 'Small Island Developing States and Their Economic Vulnerabilities’. World Development, 23 (9): 1615-32.

Chand, R. (2005). 'Post WTO Agriculture Trade and Agenda for Negotiations on Agriculture'. Policy Brief No. 23. New Delhi: National Centre for Agricultural Economics and Policy Research.

Fiji Islands Bureau of Statistics (2004). Key Statistics. December. Suva.

Food and Agriculture Organization (FAO) (2003). FAO Bulletin of Statistics, 42. Rome: FAO.

Food and Agriculture Organization (FAO) (2004). FAOSTAT. Available at: www.faostat.fao.org. Accessed 14 December.

Food and Agriculture Organization (FAO) (various years). Production Yearbook. Rome: FAO.

Food and Agriculture Organization (FAO) (various years). Trade Commerce Yearbook. Rome: FAO.

Kakazu, H. (1994). Sustainable Development of Small Island Economies. Boulder: Westview Press.

McKenzie, E., B. Prasad, and A. Kaloumaria (2005). Economic Impact of Natural Disasters on Development in the Pacific, vols 1 and 2. Canberra: AusAID.

National Food and Nutrition Committee (1997). 'The Plan of Action for Nutrition'. November. Suva: National Food and Nutrition Committee. 
Prasad, B., and C. Tisdell (1996). 'Institutional Constraints to Economic Development: The Case of Native Land Rights in Fiji'. Asia-Pacific Development Journal, 3 (2): 49-71.

Rappaport, J., E. Muteba, and J. J. Therattil (1971). Small States and Territories: Status and Problems. New York: Arno Press for the United Nations, 34-35.

Secretariat of Pacific Community (SPC) (2000). Selected Pacific Economies-A Statistical Summary No. 15. Noumea, New Caledonia: Secretariat of Pacific Community.

Sharma, K. L. (2004). 'Growth, Inequality and Poverty in Fiji Islands: Institutional Constraints and Issues'. Working Paper No. 10. Suva: Department of Economics, The University of the South Pacific.

Srinivasan, T. N. (1986). 'The Costs and Benefits of Being a Small, Remote, Island, Land Locked, or Mini State Economy’. Research Observer, 1 (2): 205-18.

Streeten, P. (1993). 'The Special Problems of Small Countries'. World Development, 21 (2): 197-202.

Thompson, R. L. (1999). 'Technology, Policy and Trade: The Key to Food Security and Environmental Protection', in C. H. Peters and J. V. Braun (eds), Food Security, Diversification and Resource Management: Refocusing the Role of Agriculture. Proceedings of the Twenty-third International Conference of Agricultural Economists. Aldershot: Ashgate.

Timmer, C. P. (1997). 'Food Securities Strategies: The Asian Experience'. FAO Agricultural Policy and Economic Development Series 3. Rome: FAO.

UNESCAP (2003). 'Statistical Indicators for Asia and the Pacific'. Bangkok: UNESCAP. Available at: www.unescap.org/stat/data/apif/index.asp.

United Nations Development Programme (UNDP) (2004). Human Development Report 2004. New York: UNDP. 